J. Clin. Chem. Clin. Biochem.

Vol. 21, 1983, pp. 69-75

\title{
Methyl $17 \beta$-Carboxyester Derivatives of Natural and Synthetic Glucocorticoids: \\ Correlation Between Receptor Binding and Inhibition of in vitro Phytohaemagglutinin-Induced Lymphocyte Blastogenesis
}

\author{
By B. Manz, H. J. Grill, R. Kreienberg, M. Rehder, K. Pollow
}

Abteilung für Experimentelle Endokrinologie, Johannes Gutenberg-Universität, Mainz, and

\section{Köhler}

Institut für Biochemie, Zentrale Abteilung Spektroskopie, Deutsches Krebsforschungszentrum, Heidelberg

(Received March 3/July 29, 1982)

Summary: Several methyl $17 \beta$-carboxyester derivatives of natural and fluorinated glucocorticoids were synthesized in order to compare their potency to compete for $\left[{ }^{3} \mathrm{H}\right]$ dexamethasone binding sites in human spleen tumour cytosols (as a source of large quantities of white blood cells) with their potency to inhibit phytohaemagglutinin-induced blastogenesis of normal human peripheral lymphocytes. The $17 \beta$-carboxylic acids neither show binding activity nor inhibition of blastogenesis. Methylation partially restores the binding capacity and the intensity of this effect depends on the kind of ring substitutions. The sequence of binding potency is identical compared to that of parent steroids and was found to be in the following order: desoximetasone $>$ dexamethasone $>$ corticosterone $>$ cortisol $>$ progesterone $>17$-hydroxyprogesterone. The phytohaemagglutinin-induced stimulation of $\left[{ }^{3} \mathrm{H}\right]$ thymidine incorporation resembles the order of binding potency. The methyl 17 $\beta$-carboxyester derivatives of progesterone, 17-hydroxyprogesterone and betamethasone are inactive. The N-benzyl 17 $\beta$-carboxamide analogs of dexamethasone and betamethasone behave like their corresponding carboxyesters, suggesting an important influence of the side chain conformation of $17 \beta$-carboxyl derivatives on glucocorticoid receptor binding.

Methylester der 173-Säuren natürlicher und synthetischer Glucocorticoide: Korrelation zwischen Rezeptor- Bindung und Hemmung der in vitro durch Phytohämagglutinin induzierten Lymphocyten-Blastogenese

Züsammenfassung: Żahlreiche Methylester von $17 \beta$-Säuren natürlicher und fluorierter Glucocorticoide wurden in der Absicht synthetisiert, ihre Eigenschaften hinsichtlich Kompetition mit $\left[{ }^{3} \mathrm{H}\right]$ Dexamethason um die Reżeptor-Bindung im Cytosol humaner Milztumoren (eine Quelle großer Mengen weißer Blutzellen) mit denen der Hemmung durch Phytohämagglutinin induzierter Blastogenese normaler humaner peripherer Lymphocyten zu vergleichen.

Die 17 $\beta$-Säuren zeigen weder Bindungsaktivität noch Hemmung der Blastogenese.

Methylierung führt zu einer partiellen Wiederherstellung der Bindungsaktivität, wobei die Intensität abhängig von der Art der Substituenten ist. Die Reihenfolge der Bindungsaffinität, bezogen auf das Ausgangssteroid, 
war wie folgt: Desoximetason $>$ Dexamethason $>$ Corticosteron $>$ Cortisol $>$ Progesteron $>17$-Hydroxyprogesteron. Die durch Phytohämagglutinin induzierte Hemmung des $\left[{ }^{3} \mathrm{H}\right]$ Thymidin-Einbaus spiegelt die Bindungseigenschaften der einzelnen Derivate am Rezeptor wider.

Die Methylderivate der 17 $\beta$-Säuren von Progesteron, 17-Hydroxyprogesteron und Betamethason waren inaktiv. Die N-Benzyl-17 $\beta$-Carboxamid-Analoga von Dexamethason und Betamethason zeigtẹn ähnnlichẹ Eigenschaften wie ihre korrespondierenden Ester, was die Vermutung nahe legt, daß die Seitenketten-Konformation der 17 $\beta$-Säure-Derivate einen erheblichen Einfluß auf die Bindung am Glucocorticoid-Rezeptor zur Folge hat.

\section{Introduction}

The mechanism of action of glucocorticoids has been intensively investigated (for a review see l.c. (1)). The steroid is thought to enter its target cell and to bind with high affinity and specificity to a cytosolic receptor protein.

Specific receptors for glucocorticoids can be identified in purified subpopulations of human mononuclear cells (e.g. T lymphocytes, non-T lymphocytes and monocytes). On the basis of quantity, binding affinity and specificity, these receptors appear to have equilibrium dissociation constants (2) and patterns of competition (3) that are essentially identical for a variety of steroid analogs. Glucocorticoids exert profound effects on human immune functions. A variety of in vitro studies have suggested that many parameters of lymphocyte function are inhibited by glucocorticoids (4). These include inhibition of glucose uptake and amino acid incorporation, inhibition of mitogen-mediated blastogenesis and elaboration of a variety of lymphokines (2).

Receptors in human peripheral blood lymphocytes may be induced threefold on a per cell basis with the mitogen phytohaemagglutinin. This is accompanied by a much higher sensitivity towards macromolecular synthesis to glucocorticoid inhibition than in nonstimulated cells $(2,5,6)$.

In this report the binding potency of natural and synthetic glucocorticoids and their derivatives to glucocorticoid receptors of human spleen tumours is determined and compared with their potency to inhibit in vitro the phytohaemagglutinin-mediated blastogenesis of normal human peripheral blood lymphocytes.

\section{Materials and Methods}

\section{Chemicals}

$\left[{ }^{3} \mathrm{H}\right]$ Dexamethasone (9-fluoro-16 $\alpha$-methyl-11 $\beta, 17,21$-trihy= droxy-1,4-pregnadiene-3,20-dione) $0.74 \mathrm{TBq} / \mathrm{mmol}$ and $\left[{ }^{3} \mathrm{H}\right]$ thymidine $0.18 \mathrm{TBq} / \mathrm{mmol}$ were purchased from Amersham. Desoximetasone (9-fluoro-16 $\alpha$-methyl-11 $\beta, 21$-dihydroxy-1,4-pregnadiene-3,20-dione) was obtained from Hoechst AG; all other steroids were purchased from Sigma. The $17 \beta$-carboxylic derivatives of 21-hydroxy pregnanes (Ia-IXa) were obtained by periodic acid oxidation (7). Methylation of the acids to their corresponding methyl esters (Ib-IXb) was performed with diazomethane.

N-Benzyl 9-fluoro-16 $\alpha$-methyyl-11 $\beta, 17$-dihydroxy-3-oxo-1,4-androstadiene-17̄ $\beta$-carboxamide (Ic) and $N$-benzyl 9-fluoro-16 $\beta$ methyl-11 $\beta, 17$-dihydroxy-3-oxo-1,4-androstadiene-17 $\beta$-carboxamide (IIc) were synthesized according to Formstecher et al. (7). The synthesis of compound $X$ will be described elsewhere (6).

\section{Preparation of cytosols}

Humañ spleen tumour tissue was stored at $-70^{\circ} \mathrm{C}$ until use. After thawing in homogenization buffer $(20 \mathrm{mmol} / \mathrm{l} \mathrm{Tris} / \mathrm{HCl}, 2.73$ $\mathrm{mol} / \mathrm{l}$ glycerol, $2 \mathrm{mmol} / 1 \mathrm{CaCl}_{2}, 1 \mathrm{mmol} / 1 \mathrm{MgCl}_{2}, 5 \mathrm{mmol} / \mathrm{lmer}$ captoethanol, $\mathrm{pH} 7.4$ ), the tissue was minced in 3 volumes of buffer and homogenized by 10 strokes of a teflon/glass Potter/Elvehjem homogenizer. The homogenate was centrifuged for $45 \mathrm{~min}$ at $105000 \mathrm{~g}$ and the supernatant taken as cytosol:

\section{Competition ạsay}

The tübes were prepared as follows: To each tube $0.1 \mathrm{ml}$ of $\left[{ }^{3} \mathrm{H}\right]$ dexamethasone (in homogenization buffer) was pipetted, to give a final concentration of $32 \mathrm{nmol} / \mathrm{l}$. Then aliquots of $0.1 \mathrm{ml}$ containing the various competitors (in homogenization buffer) at 10 different concentrations (3.2-640 nmol/l) were added. Finally $0.2 \mathrm{ml}$ of cytosol were added to each tube and the tubes were incubated for $4 \mathrm{~h}$ at $0{ }^{\circ} \mathrm{C}$. Incubation was terminated by the addition of $1 \mathrm{ml}$ dextran-coated charcoal suspension. The final con= centrations were $5 \mathrm{~g} / \mathrm{l}$ of charcoal and $0.5 \mathrm{~g} / \mathrm{l}$ of dextran $\mathrm{T} \dot{5} 00$. After $10 \mathrm{~min}$ of incubation the tubes were centrifuged for $10 \mathrm{~min}$ at $5000 \mathrm{~g}$ and $1 \mathrm{ml}$ of the supernatant was withdrawn and counted for radioactivity. All determinations were carried out in triplicate. The relative binding affinities of the steroids for cytosolic glucocorticoid receptors were determined as described by Ojasoo \& Raynaud (8). The relative binding affinity of dexamethasone was taken to be equal to 100 .

\section{$\left[{ }^{3} \mathrm{H}\right]$ Thymidine inçorporation assay}

Peripheral blood lymphocytes from healthy donors were isolated using a Ficoll Hypaque double gradient technique (12). The cells were washed three times in Hanks balanced salt solution and resuspended at a cell concentration of $10^{4} / 1$ in medium 199 (Flow Laboratories, Meckenheim, F.R.G.) supplemented with $50 \mathrm{ml} / 1$ heat-inactivated serum from healthy donors belonging to blood group AB, $2 \mathrm{mmol} / \mathrm{l} L$-glutamine, $100000 \mathrm{U} / \mathrm{I}$ penicillin (Sigma, München, F.R.G.) and $100 \mathrm{mg} / \mathrm{l}$ streptomycin (Sigma, Münchẹn, F.R.G.). More than $95 \%$ of the lymphocytes were viable as determined by trypan blue exclusion. $200 \mu \mathrm{l}$ of culture medium, con= taining $2 \times 10^{5}$ cells, were added to each well of round bottomed microtiter plates, $10 \mu$ l of phytohaemagglutinin P dilutions (Difco Laboratories, Detroit, Michigan, USA, $5 \mathrm{mg} / \mathrm{l}$ phytóhaemagglutinin) and $10 \mu \mathrm{l}$ of steroid solutions of increasing concentrations dissolved in $9 \mathrm{~g} / \mathrm{l} \mathrm{NaCl}$ were added to each well and incubated for $72 \mathrm{~h}$ at $37^{\circ} \mathrm{C}$ in a humified atmosphere of $5 \% \mathrm{CO}_{2}$ and $95 \%$ air. Lymphocyte stimulation was assessed by the incorporation of $\left[{ }^{3} \mathrm{H}\right]$ thymidine into the DNA during the last $4 \mathrm{~h}$ of culture (3.6 MBq/1). 


\section{Results and Discussion}

In recent years a multitude of novel side-chain modified glucocorticoids have been synthesized. In principle, three different chemical pathways are accessible: elongation of the side-chain $(4,10-13)$, introduction of reactive groups by retaining 21 carbon atoms $(14,15)$, and oxidation of the side chain to the corresponding $17 \beta$-carboxylic acid analog $(12-14)$. The latter are the topic of this study.

To investigate the influence of a side-chain modification on the biological activity of a family of glucocorticoid analogs, we selected $17 \beta$-carboxylic acids and their methylester analogs. They are easily accessible and the yields are almost quantitative (7). The three $17 \beta$-carboxamide analogs of dexamethasone used in this study were synthesized according to Formstecher et al. (7) with the exception that the $\mathrm{N}$-hydroxysuccinimide active ester analog of dexamethasone was reacted with the respective amine.

Depending on the histological classification of lymphogranulomatosis maligna (Hodgkins disease) human spleen tumours contain varying amounts of white blood cells. Figure 1a shows the saturation kinetics of the cytosolic glucocorticoid receptor with $\left[{ }^{3} \mathrm{H}\right]$ dexamethasone. Specific binding is a hyperbolic function of the free dexamethasone concentration, and a Scatchard plot of the data is compatible with a single population of binding sites (fig. 1b). Human spleen tumour cytosols, so far investigated, contained glucocorticoid receptor concentrations of 40-150 fmol/mg cytosol protein. Linear regression analysis of Scatchard plots gave an apparent $K_{\text {diss }}$ at $0^{\circ} \mathrm{C}$ of $6.8 \pm 2.1 \mathrm{nmol} / \mathrm{l}$. This is in good agreement with the equilibrium dissociation constants found for the glucocorticoid receptors of T-lymphocytes, nonT lymphocytes and monocytes in partly purified subpopulations of human mononuclear cells (2). Not only are the dissociation constants similar but binding specificity studies revealed similar patterns of competition by a variety of steroid analogs in all human spleen tumours so far tested, independent of the histological classification. Thus human spleen tumours embody an ideal source of very large quantities "of glucocorticoid receptor positive tissues.

The relative binding affinities of the steroids to the spleen tumour glucocorticoid receptor are listed in table 1. As described for rat hepatoma tissue culture cells (19), substitutions like 11-oxo, 17-hydroxyl and 21-deoxy consistently reduce the affinity for the receptor, whereas the oxidation of the side-chain to androstane derivatives yields inactive steroids. Methylation partly restores the binding capacity and the value of this effect is subject to the kind of ring substitutions. Figure 2 clearly proves this observation and shows that the 17-hydroxyl group has the same unfavourable effect on the binding to the glucocorticoid receptor of human spleen tumour leukocytes as observed in other systems $(16,18)$.

The sequence of potencies for the $17 \beta$-carboxyesters is identical to that of parental steroids (fig. 3 ) and was found to be desoximetasone $>$ dexamethasone $>$ corticosterone $>$ cortisol $>$ progesterone $>17$ hydroxyprogesterone. Interestingly, the methyl $17 \beta$ carboxyester analog of betamethasone (IIb) deviates from the rule. Although the binding of dexamethasone (16 $\alpha$-methyl) to glucocorticoid receptors cannot be distinguished from that of betamethasone (16 $\beta$-methyl), compound $\mathrm{IIb}$ is, if at all, only a very weak competitor. This is in good agreement with the binding affinities found for $16 \alpha$ - and $16 \beta$-methylprogesterone, $16 \alpha$ - and $16 \beta$-methyl-17-hydroxyprogesterone and $16 \alpha$ - and 16 1 -methyl-17,21-dihydroxy-4-pregnene-3,20-dione $(18,19)$.

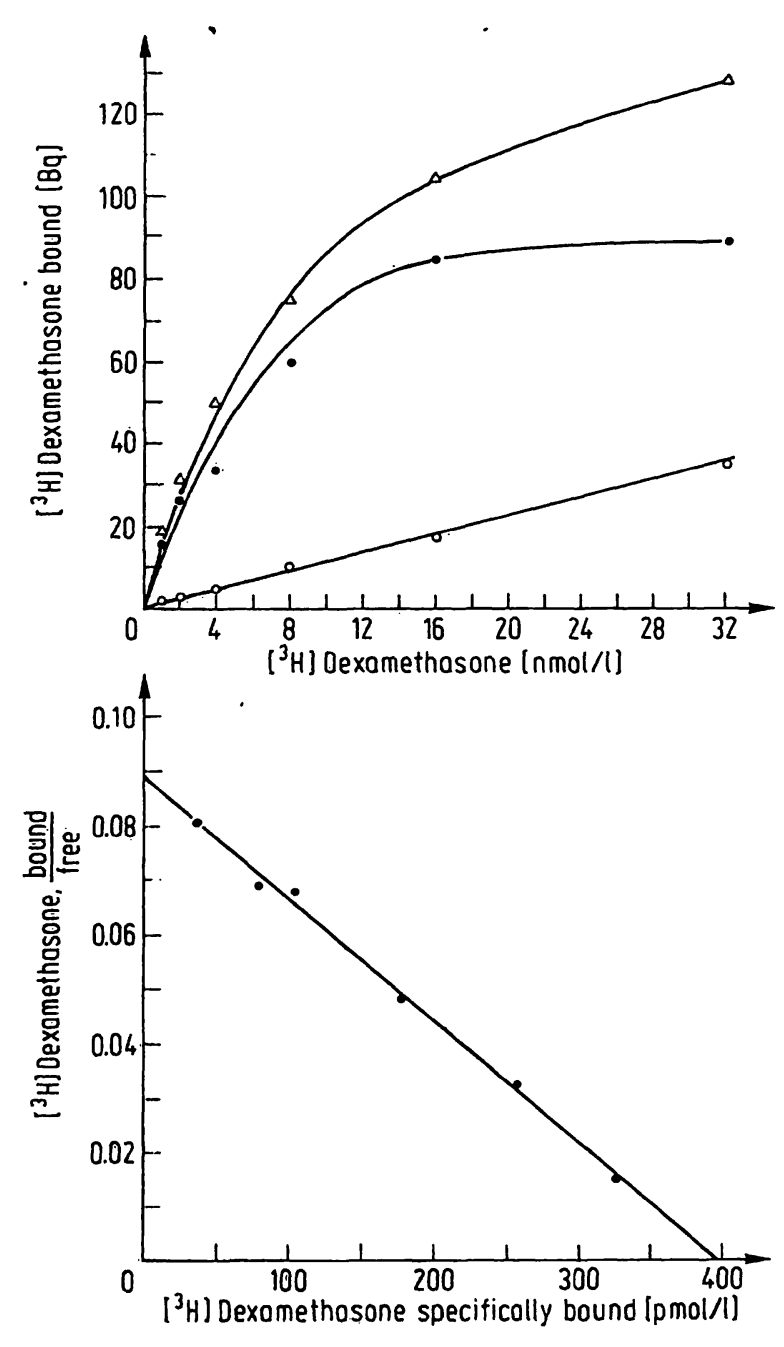

Fig. 1. Dependence of $\left[{ }^{3} \mathrm{H}\right]$ dexamethasone equilibrium binding (B) to human spleen tumour tissue cytosol on free (F) dexamethasone concentration. Nonspecific binding $(O)$ was subtracted from total binding $(\Delta)$ to glucocorticoid receptor. 
Thal. I, Steroids structures, inhilition of $\left[{ }^{3} \mathrm{l}-1\right]$ thymidine incorporation and relative binding affinities for androstane-17 $\beta$-carboxylic acids and androstince-17|3-carlonxymethylesters (siane symbols as in figs. 1 and 2).

\begin{tabular}{|c|c|c|c|c|c|c|c|c|}
\hline Compound & I-enc & $R_{1}$ & $\mathbf{R}_{2}$ & $R_{3}$ & $\mathbf{R}_{\mathbf{4}}$ & $R_{5}$ & $\begin{array}{l}\% \text { Inhibi- } \\
\left.\text { tion of }{ }^{1}\right) \\
{\left[{ }^{3} \mathrm{H}\right] \text { thymi- }} \\
\text { dine incor- } \\
\text { poration at } \\
5 \mu \mathrm{mol} / 1 \\
\text { of steroid }\end{array}$ & $\begin{array}{l}\text { Relative } \\
\text { binding } \\
\text { activity }^{2} \text { ) }\end{array}$ \\
\hline I & + & F & $\mathrm{OH}$ & $-\mathrm{CH}_{3}$ & $\mathrm{OH}$ & $\mathrm{CH}_{2} \mathrm{OH}$ & 100 & 100 \\
\hline II & + & $\mathrm{F}$ & $\mathrm{OH}$ & $\mathrm{B}-\mathrm{CH}_{3}$ & $\mathrm{OH}$ & $\mathrm{CH}_{2} \mathrm{OH}$ & 100 & 100 \\
\hline III & + & $\mathbf{F}$ & $\mathrm{OH}$ & $-\mathrm{CH}_{3}$ & $\mathbf{H}$ & $\mathrm{CH}_{2} \mathrm{OH}$ & 100 & 140 \\
\hline IV & + & $\mathrm{H}$ & $\mathrm{OH}$ & H & $\mathrm{OH}$ & $\mathrm{CH}_{2} \mathrm{OH}$ & 80 & 35 \\
\hline V & - & $H$ & 0 & $H$ & $\mathrm{OH}$ & $\mathrm{CH}_{2} \mathrm{OH}$ & 10 & 2 \\
\hline VI & - & $H$ & $\mathrm{OH}$ & $H$ & $\mathrm{OH}$ & $\mathrm{CH}_{2} \mathrm{OH}$ & 100 & 45 \\
\hline VII & - & $\mathrm{H}$ & $\mathrm{OH}$ & $H$ & H & $\mathrm{CH}_{2} \mathrm{OH}$ & 100 & 80 \\
\hline VIII & - & $\mathrm{H}$ & $H$ & $\mathbf{H}$ & $\mathrm{OH}$ & $\mathrm{CH}_{3}$ & 0 & 0.8 \\
\hline IX & - & $H$ & $H$ & $H$ & $H$ & $\mathrm{CH}_{3}$ & 0 & 10 \\
\hline la & + & $F$ & $\mathrm{OH}$ & $-\mathrm{CH}_{3}$ & $\mathrm{OH}$ & $\mathrm{OH}$ & 0 & 0.1 \\
\hline IIa & + & F & $\mathrm{OH}$ & $\beta-\mathrm{CH}_{3}$ & $\mathrm{OH}$ & $\mathrm{OH}$ & 0 & 0.1 \\
\hline IIIa & + & $F$ & $\mathrm{OH}$ & $-\mathrm{CH}_{3}$ & $\mathbf{H}$ & $\mathrm{OH}$ & 0 & 0.1 \\
\hline IVa & + & $\mathrm{H}$ & $\mathrm{OH}$ & H & $\mathrm{OH}$ & $\mathrm{OH}$ & 0 & 0.1 \\
\hline$V a$ & - & $H$ & 0 & $\mathrm{H}$ & $\mathrm{OH}$ & $\mathrm{OH}$ & 0 & 0.1 \\
\hline Vla & - & $\mathrm{H}$ & $\mathrm{OH}$ & $\mathbf{H}$ & $\mathrm{OH}$ & $\mathrm{OH}$ & 0 & 0.1 \\
\hline VIIa. & - & $\mathrm{H}$ & $\mathrm{OH}$ & $\mathrm{H}$ & $\mathrm{H}$ & $\mathrm{OH}$ & 0 & 0.1 \\
\hline VIIIa & - & $\mathrm{H}$ & $\mathbf{H}$ & $\mathrm{H}$ & $\mathrm{OH}$ & $\mathrm{OH}$ & 0 & 0.1 \\
\hline$I X a$ & - & $\mathrm{H}$ & $\mathrm{H}$ & $\mathbf{H}$ & $\mathrm{H}$ & $\mathrm{OH}$ & 0 & 0.1 \\
\hline Ib & + & F & $\mathrm{OH}$ & $-\mathrm{CH}_{3}$ & $\mathrm{OH}$ & $\mathrm{OCH}_{3}$ & 74 & 32 \\
\hline 11b & + & F & $\mathrm{OH}$ & $\beta-\mathrm{CH}_{3}$ & $\mathrm{OH}$ & $\mathrm{OCH}_{3}$ & 0 & 0.1 \\
\hline IIIb & + & F & $\mathrm{OH}$ & $-\mathrm{CH}_{3}$ & $\mathrm{H}$ & $\mathrm{OCH}_{3}$ & 92 & 100 \\
\hline IVb & + & $\mathrm{H}$ & $\mathrm{OH}$ & H & $\mathrm{OH}$ & $\mathrm{OCH}_{3}$ & 12 & 0.6 \\
\hline $\mathrm{Vb}$ & - & $\mathrm{H}$ & $\mathrm{O}$ & $\mathrm{H}$ & $\mathrm{OH}$ & $\mathrm{OCH}_{3}$ & 0 & 0.1 \\
\hline VIb & - & $\mathrm{H}$ & $\mathrm{OH}$ & $\mathbf{H}$ & $\mathrm{OH}$ & $\mathrm{OCH}_{3}$ & 8 & 0.8 \\
\hline VIIh & - & $H$ & $\mathrm{OH}$ & $\mathbf{H}$ & $\mathbf{H}$ & $\mathrm{OCH}_{3}$ & 32 & 6.6 \\
\hline Vlllib & - & $\mathrm{H}$ & $H$ & $\mathbf{H}$ & $\mathrm{OH}$ & $\mathrm{OCH}_{3}$ & 0 & 0.1 \\
\hline IX'b & - & $H$ & $\mathrm{H}$ & $\mathbf{H}$ & $\mathbf{H}$ & $\mathrm{OCH}_{3}$ & 0 & 0.1 \\
\hline Ic & + & F & $\mathrm{OH}$ & $-\mathrm{CH}_{3}$ & $\mathrm{OH}$ & $\mathrm{NH}-\mathrm{CH}_{2}-\mathrm{C}_{6} \mathrm{H}_{5}$ & 85 & 27 \\
\hline IIc & + & $\mathrm{F}$ & $\mathrm{OH}$ & $\beta-\mathrm{CH}_{3}$ & $\mathrm{OH}$ & $\mathrm{NH}-\mathrm{CH}_{2}-\mathrm{C}_{6} \mathrm{H}_{5}$ & 0 & 0.1 \\
\hline $\mathrm{x}$ & + & $\mathbf{F}$ & $\mathrm{OH}$ & $-\mathrm{CH}_{3}$ & $\mathrm{OH}$ & NH X & 60 & 3.2 \\
\hline
\end{tabular}<smiles>[R6]C(=O)C1([R])C([R6])CC2C3CCC4=CC(=O)C=CC4(C3[R])C2(C)CC1[R]</smiles><smiles>[Y]C(CC(=O)OC(C)(C)C)C(=O)OC(C)(C)C</smiles>

1) Effects of different stcroids on [ $\left.{ }^{3} \mathrm{H}\right]$ thymidine incorporation into purified human peripheral blood lymphocytes. Results shown are for cells stimulated for $72 \mathrm{~h}$ with phytohaemagglutinin.

$\left.{ }^{2}\right)$ Relative binding activity, with dexamethasone taken as 100 (means of triplicate determinations).

With the N-benzyl analogs of dexamethasone (Ic) and betamethasone (IIc), we could show that this was not an abnormal result, in that a $16 \beta$-methyl substitution again led to an inactive derivative. As already shown by Schmit \& Rousseau (18), one cannot ascribe the extremely low affinities of $16 \beta$-methyl compounds a priori to steric hindrance (tab. 1, compound $X$ ) since on the other hand the $16 \beta$-methyl substitution of betamethasone (II) does not de- crease the affinity of this steroid for the receptor. We think these results confirm the hypothesis of Schmit \& Rousseau (18) that receptor binding involves a specific conformation of the side chain.

Steroids have been classified according to their mode of action, based on dose response curves for the induction of tyrosine aminotransferase (EC 2.6.1.5) in rat hepatoma tissue culture cells. Optimal and sub- 


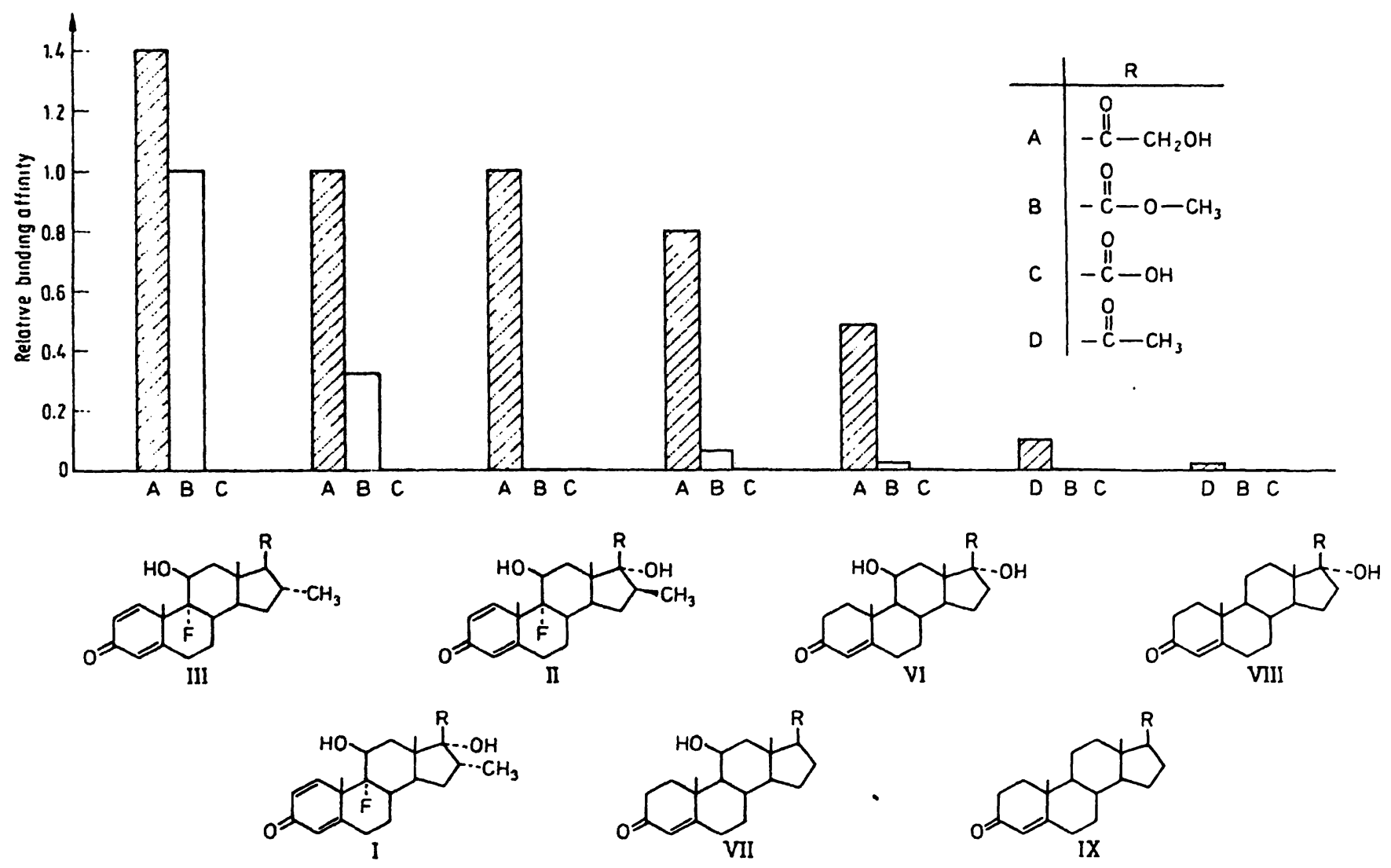

Fig. 2. Binding affinities of natural and synthetic corticoids. their $17 \beta$-carboxylic acids and methyl csters to the glucocorticoid receptor of human spleen tumour leukocytes. The binding affinities of the $17 \beta$-carboxyesters (open bars) are always lower than, but proportional to the binding affinities of the parent steroids (shaded bars). The only exception is the carboxyester of betamethasone (IIb) which bears a $16 \beta$-methyl group. The $17 \beta$-carboxylic acids do not compete for $\left[{ }^{3} \mathrm{H}\right]$ dexamethasone binding to the glucocorticoid receptor. All data are means of triplicate determinations.

optimal inducers raise the basal tyrosine aminotransferase levels whereas antiinducers are unable to stimulate tyrosine aminotransferase synthesis. The latter, however, can decrease the enzyme induction by optimal or suboptimal inducers (20). Recently, Rousseau et al. (16) reported, that $17 \beta$-carboxamide analogs of dexamethasone, desoximetasone and hydrocortisone represent a new class of glucocorticoid antagonists. This antiglucocorticoid effect was found to be dose-dependent and the order of potency of the inhibitors was consistent with their respective affinities for rat hepatoma tissue culture cell glucocorticoid receptors.

Comparable results were found for the $17 \beta$-carboxyester analog of dexamethasone Ib in vivo. Although compound Ib and hydrocortisone (compound VI) possess similar binding affinities, only hydrocortisone is able to raise the levels of tyrosine amino= transferase and tryptophan-2,3-dioxygenase (EC 1.13.11.11) in the livers of adrenalectomized rats (17).

In contrast to rat liver [where methyl $17 \beta$-carboxyester derivatives of dexamethasone (Ib) or hydrocortisone (VIb) are not able to raise tyrosine aminotransferase and tryptophan-2,3-dioxygenase activities

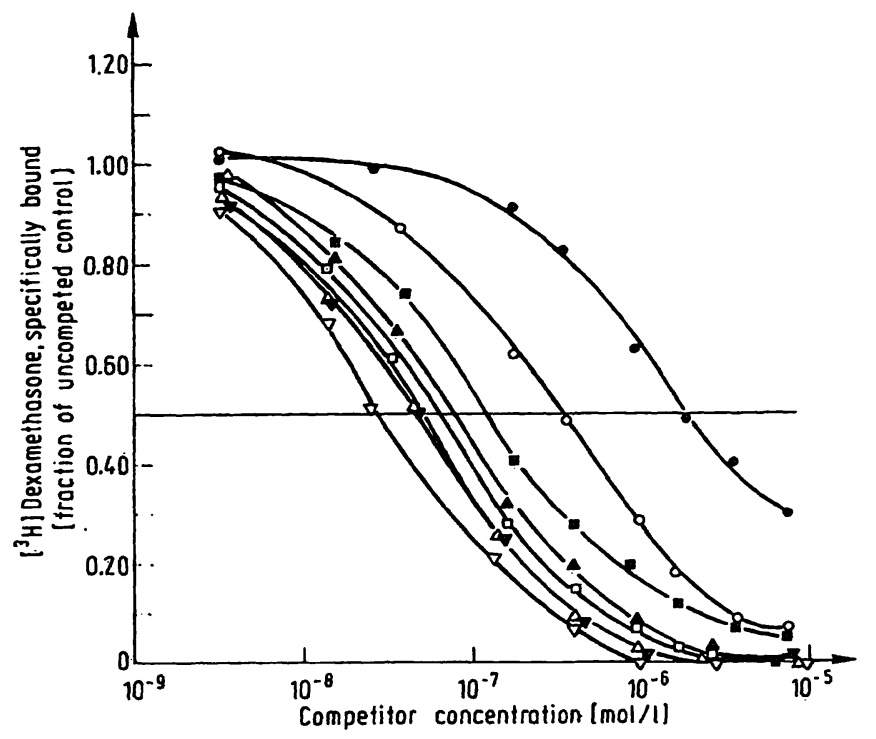

Fig. 3. Competition of synthetic and natural corticoids for $\left[{ }^{3} \mathrm{H}\right]$ dexamethasone in human spleen tumour cytosol. Aliquots of cytosol were incubated with $32 \mathrm{nmol} / \mathrm{l}\left[{ }^{3} \mathrm{H}\right] \mathrm{dexa}-$ methasone plus $640-3.2 \mathrm{nmol} / \mathrm{h}$ competitors for $18 \mathrm{~h}$ at $0^{\circ} \mathrm{C}$. Total binding in the absence of competitors minus binding in the presence of $640 \mathrm{nmol} / \mathrm{l}$ dexamethasone (nonspecific binding) was taken as $100 \%$ scale. Unbound steroids were removed using dextran-coated charcoal. The symbols are: Desoximetasone $(\nabla)$, dexamethasone $(\Delta)$, betamethasone $(\nabla)$, corticosterone $(\square)$, cortisol ( $\Delta)$, prednisolone ( $\square)$, progesterone $(O)$ and 17-hydroxyprogesterone (O). Similar patterns of competition were found in all human spleen tumour cytosols, independent of the histological classification. 
(17)], or to rat hepatoma tissue culture cells [where $17 \beta$-carboxamide derivatives behave like glucocorticoid antagonists and are, if at all, only extremely weak agonists (16)], the same (carboxamide Ic) or related (carboxyesters Ib, IIIb, IVb) derivatives behave like glucocorticoid agonists and inhibit phytohaemagglutinin-mediated stimulation of $\left[{ }^{3} \mathrm{H}\right]$ thymidine incorporation in normal peripheral blood lymphocytes (tab. 1 and fig. 4). The order of inhibition resembles that of binding affinities to the glucocorticoid receptors of human spleen tumour cytosol (tab. 1) and was found to be the same in three differently stimulating phytohaemagglutinin and concanavalin A concentrations (data not shown). The methyl $17 \beta$-carboxyester derivatives of progesterone and 17-hydroxyprogesterone do not inhibit blastogenesis up to $5 \mu \mathrm{mol} / 1$ steroid in the culture medium. This is consistent with the very low affinities of these compounds to the glucocorticoid receptor (tab. 1). Clemens et al. (21) recently showed that $1-20 \mathrm{mg} / 1$ of progesterone, but not 17-hydroxyprogesterone, can block $\left[{ }^{3} \mathrm{H}\right]$ thymidine incorporation into mitogenstimulated human peripheral lymphocytes. They suggest that this effect is not mediated via a classical steroid hormone receptor mechanism but is more likely an inhibition of $\left[{ }^{3} \mathrm{H}\right]$ thymidine entry into the cell by progesterone itself. In contrast, in rat hepatoma tissue culture cells, progesterone behaves like a glucocorticoid antagonist competing with agonists for binding to the glucocorticoid receptor (16).

The addition of increasing concentrations $(50-500 \mathrm{nmol} / \mathrm{l})$ of the $\mathrm{N}$-benzyl $17 \beta$-carboxamide analog of dexamethasone (compound Ic) in the presence of $25 \mathrm{nmol} / \mathrm{l}$ of dexamethasone showed an additive suppression of $\left[{ }^{3} \mathrm{H}\right]$ thymidine incorporation (fig. 3). This was the more surprising, as compound Ic was found to be the most potent antiinducer in rat hepatoma tissue culture cells (16). Experiments using tritiated $17 \beta$-carboxamide analogs of dexamethasone are in progress to elucidate why the same steroid (compound Ic) inhibits phytohaemagglutinin-

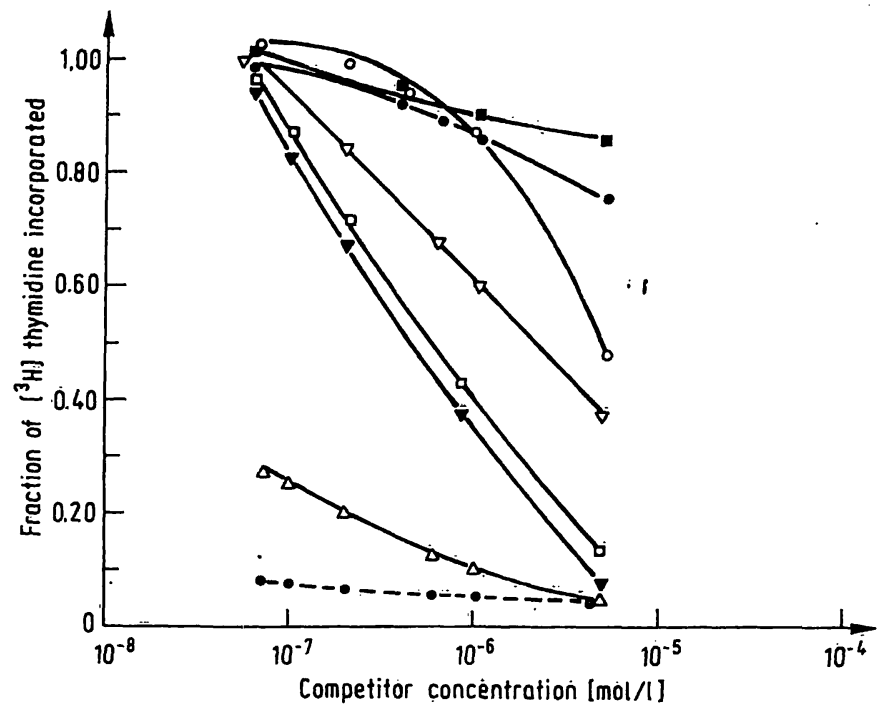

Fig. 4. Effect of steroid derivatives on $\left[{ }^{3} \mathrm{H}\right]$ thymidine incorporation in human peripheral blood lymphocytes. Peripheral blood lymphocytes were isolated as described. Cell count was adjusted to $2 \times 10^{5}$ cells per culture volume $(200 \mu \mathrm{l})$. $10 \mu \mathrm{l}$ of phytohaemagglutinin $(5 \mathrm{mg} / \mathrm{l})$ and $10 \mu \mathrm{l}$ of decreasing concentrations of steroids dissolved in $154 \mathrm{mmol} /$ $\mathrm{l}$ aqueous $\mathrm{NaCl}$ solution were added to each culture volume. Lymphocyte stimulation was assessed by the incorporation of $\left[{ }^{3} \mathrm{H}\right]$ thymidine into the DNA during the last 4 $h$ of culture. Dexamethasone $(\Delta, I)$; methyl $17 \beta$-carboxyester analogs of desoximethasone $(\square, \mathrm{MI} b)$, dexamethasone $(\nabla, \mathrm{Ib})$, betamethasone (田, IIb) and hydrocortisone (O, VIb); N-benzyl 9-fluoro-16 $\alpha$-methyl $11 \beta, 17$-dihydroxy-3=oxo-1,4-androstadiene-17 $\beta$-carboxamide $\quad(\boldsymbol{\nabla}$,

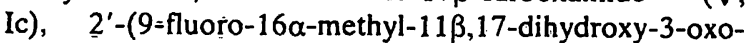
1,4-androstadiene-17 $\beta$-carboxamido)glutaric acid di-tertbutyl ester $(O, X)$. N-benzyl $17 \beta$-carboxamide $(\nabla, I c)+$ $50 \mathrm{nmol} / \mathrm{l}$ dexamethasone $(\Delta, \mathrm{I})$ is symbolized by $(0---0)$. Similar results were found in peripheral blood lymphocytes of different donors. In this particular experiment absolute radioactivity of background and maximum incorporation corresponded to means of 10 and $333 \mathrm{~Bq}$, respectively.

mediated stimulation of $\left[{ }^{3} \mathrm{H}\right]$ thymidine incorporation in human peripheral lymphocytes, but antagonizes the action of dexamethasone in rat hepatoma tissue culture cells.

\section{Ackmowledgment}

We would like to thank Miss $U$. Pfeffer for her technical assistance.

\section{Appendix}

IUPAC names and melting points of methyl $17 \beta$-carboxyester and benzyl $17 . \beta$-carboxamide derivatives:

methyl 9-fluoro-16 $\alpha$-methyl-11 $\beta, 17$-dihydroxy-3-oxo-1,4-androstadiene-17 $\beta$-carboxyester (Ib; m.p. $248^{\circ} \mathrm{C}$ );

methyl 9-fluoro-16 $\beta$-methyl-11 $\beta, 17$-dihydroxy-3-oxo-1,4-androstadiene-17 $\beta$-carboxyester (IIb; m.p. $224-226^{\circ} \mathrm{C}$ );

methyl 9-fluoro-16 $\alpha$-methyl-11 $\beta$-hydroxy-3-oxo-1,4-androstadiene-17 $\beta$-carboxyester (IIIb; m.p. 234-235 ${ }^{\circ} \mathrm{C}$ );

methyl 11 17 -hyd-17-dihydroxy-3-oxo-1,4-androstadiene-17 $\beta$-carboxyester (IVb; m.p. 196-197 ${ }^{\circ} \mathrm{C}$ );

methyl $11 \beta$ - 3 - $228^{\circ} \mathrm{C}$ );

methyl $11 \beta$-hydroxy-3-oxo-4-androstene-17 $\beta$ - $17 \beta$-carboxyester (VIb; m.p. 199-201 ${ }^{\circ} \mathrm{C}$ );

methyl 17-hydroxy-3-oxo-4-androstene-17 $\beta$-carboxyester (VIIb; m.p. 180-182 ${ }^{\circ} \mathrm{C}$ );

methyl 17-hydroxy-3-oxo-4-androstene-17 $\beta$-carboxyester (VIIIb; m. p. 205-207 ${ }^{\circ} \mathrm{C}$ );

$\mathrm{N}$-benzyl 9 -flu-androstene-17 $\beta$-carboxyester (IXb; m.p. $170-171^{\circ} \mathrm{C}$ );

$\mathrm{N}$-benzyl 9-fluoro-16 $\alpha$-methyl-11 $\beta, 17$-dihydroxy-3-oxo-1,4-androstadiene-17 $\beta$-carboxamide (Ic; m.p. $258^{\circ} \mathrm{C}$ );

$2^{\prime}$-(9-fluoro-16 $\alpha$-methyl-11 $\beta, 17$-dihydroxy-3-oxo-1 4-and

$215^{\circ} \mathrm{C}$ ). 


\section{References}

1. Higgins, S. J. \& Gehring, U. (1978) Cancer Res. 28, 313.

2. Lippman, M. E. (1979) Glucocorticoid Hormone Action (Baxter, J. D. \& Rousseau, G. G. eds.) Springer-Verlag, Heidelberg, New York.

3. Lippman, M. E. \& Barr, R. D. (1977) J. Immunol. 118, 1977-1981.

4. Fauci, A. S., Dale, D. C. \& Balow, J. E. (1976) Ann. Intern. Med. 84, 304-315.

5. Ono, T., Terayama, H., Tataku, F. \& Nakao, K. (1968) Biochim. Biophys. Acta 161, 361-367.

6. Manz, B., Grill, H. J. \& Pollow, K. (1982) J. Steroid Biochem. 17 , in press.

7. Formstecher, P., Lustenberger, P. \& Dautrevaux, M. (1980) Steroids 35, 265-272.

8. Ojasoo, T. \& Raynaud, J. P. (1978) Cancer Res. 38, 4186-4198.

9. Agnado, M. T., Pujol, N., Rubiol, E., Tura, M. \& Celado, A. (1980) J. Immunol. Methods 32, 41-50.

10. Simons, S. S. Jr., Thompson, E. B. \& Johnson, D. T. (1979) Biochemistry 18, 4915-4922.

11. Daxenbichler, G., Grill, H. J., Domanig, R., Moser, E. \& Dapunt, O. (1980) J. Steroid Biochem. 13, 489-493.
12. Govindan, M. V. \& Manz, B. (1980) Eur. J. Biochem. 108, 47-53.

13. Simons, S. S. Jr. \& Thompson, E. B. (1981) Proc. Natl. Acad. Sci. USA 78, 3541-3545.

14. Wolf, M. E., Baxter, J., Kollman, P. A., Lee, D. L., Kuntz, I. O., Bloom, E., Matulichi, D. \& Morris, J. (1978) Biochem. 14, 1750-1759.

15. Manz, B. \& Govindan, M. V. (1980) Hoppe-Seyler's Z. Physiol. Chem. 361, 953-957.

16. Rousseau, G. G., Kirchhoff, J., Formstecher, P. \& Lustenberger, P. (1979) Nature 279, 158-160.

17. Manz, B. \& Govindan, M. V. (1979) Cancer Treatment Reports $63,1158$.

18. Schmit, J.-P. \& Rousseau, G. G. (1977) J. Steroid Biochem. 8, 921-928.

. 19. Rousseau, G. G. \& Schmit, J.-P. (1977) J. Steroid Biochem. 8, 911-920.

20. Samuels, H. H. \& Tomkins, G. M. (1970) J. Molec. Biol. 52, 57-74.

21. Clemens, L. E., Siiteri, P. K. \& Stites, D. P. (1979) J. Immunol. $122,1978-1985$.

Dr. rer. nat. Bernhard Manz

Abteilung für Experimentelle Endokrinologie

Johannes Gutenberg-Universität Mainz

Langenbeckstr. 1

D-6500 Mainz 
